\title{
Prospects for creating a digital service E-Lean- Hub in a lean university model
}

\author{
Irina Maslova ${ }^{1, *}$, Rasulya Aetdinova ${ }^{2}$, Aleksandr Koskin ${ }^{1}$ and KristinaDudina ${ }^{1}$ \\ ${ }^{1}$ Orel state University, 302020 Naugorskoe highway, Russia. \\ ${ }^{2}$ Kazan Federal University, 423809 Naberezhnye Chelny Institute, Russia.
}

\begin{abstract}
Modern universities are small cities. They have libraries, sports complexes, swimming pools, dormitories, catering, auditoriums, payment centres, and payment terminals. There are residents in them - students, teachers and employees, there are guests - applicants, parents, employers, and partners. In order to let all these work, the proper and effective management system is to be developed. Each resident and guest of the university should have an appropriate access to the resources and services according to their role. The development of digital technologies in a single university is not yet an indicator of quality of education since such technologies are just a tool. Universities are implementing a non-profit mission, but processes are becoming more and more business units, which involves the use of business management technologies in education to increase its effectiveness in the digital economy. In order to learn how to use it in a most effective way, experience of the foreign universities where such a model is already well applied and developed is crucial. In this regard, the article considers the mechanism of implementation of this system.
\end{abstract}

\section{Introduction}

Universities are mostly state institutions that fulfill state educational and scientific orders and are often not located in the market environment. Reforming the system of funding distribution in Russia follows the path of stratification of higher education institutions by groups of leaders and groups of regional universities, which leads to a fixed level of funding. When changing approaches to financing and switching to the model of Autonomous universities, it becomes almost necessary to introduce the concept of lean production in the higher education system.

One of the tasks is to develop a system of criteria and indicators for the quality of University management based on the lean principles. Undoubtedly, in the era of the global knowledge economy, higher education will not remain the same. Is the introduction of new tools and technologies in all spheres of University activity: the content of education in applied educational technology in knowledge management, in the organization of educational process, monitoring system, etc.

A single open and transparent educational system based on the Lean management model

\footnotetext{
${ }^{*}$ Corresponding author: cakyra_04@mail.ru
} 
will ensure the mobility of students and teachers from the regions of the partner countries, as well as from other EU countries. This will also allow attracting foreign teachers, organizing foreign internships, student exchanges, international research, etc. Such events will allow universities to become part of the international educational space, while maintaining their unique qualities and competitive advantages.

The transition to Lean University in countries involves the introduction of more flexible and seamless processes, changing the corporate culture, optimizing processes, increasing transparency and efficiency of activities, and compliance with Quality assurance.

\section{Results and Discussion}

Trends in the global development of society show that the education system is on the verge of forming a new concept and new approaches to education. Reformatting the role of universities as major business players that set trends in innovation and training, the transition to the digital economy, the formation of new global technology platforms, and the birth of the fourth industrial revolution - in technological areas on the one hand and the need for subtly and ethically take into account the needs of the individual, to calculate ecological and economic consequences of the activities, build values and ethical principles in new terms, to revise the ethical approaches of development of technologies in line with the concept of sustainable development lead to the need to revise the approach to quality assurance, on the basis of modern digital technologies, and on the basis of relevant management concepts. Universities are now, on the one hand, a non-productive social sector, and on the other hand, they are increasingly becoming prominent business entities that can generate a significant flow of added value, which allows us to consider their processes from the point of view of the best business management practices [1-2].

An analysis of the national priorities of Russian Federation in terms of digitalization of quality assurance and shows the following.

In Russia, the transition from the era of high-tech to the era of high-hume is becoming more and more popular, and the quality of education is a priority issue. Despite this, there is no systematic approach to quality assurance for trust in society. The development of the education system based on the principles of sustainable development with the use of modern management technologies and the formation of a smart educational environment relies on a number of strategic documents adopted at the Federal level [3].

Russian and international experts note that since the early 2000s, the Russian Federation has made relative progress in providing quality education (Sustainable Development Goal 4). Within the framework of the «development of education» program for 2013-2020, subprogram 5 «Improving the management of the education system» (Sustainable Development Goal 4) is being implemented. In 2019, the Russian venture company, which is one of the institutes of innovative development in the Russian Federation, together with the all-Russian certification Institute with the support of the Ministry of industry and trade of the Russian Federation, submitted for public discussion ten preliminary national standards in the field of smart production. At the Federal level, national projects are being implemented: «Education», «Science», «Digital economy», and «labor Productivity». Tools for improving labor productivity in the business environment are traditionally based on lean production tools, and «process factories» are created in higher education institutions to provide practiceoriented training in lean production. However, classical hierarchical structures are still used in education management, despite the readiness of higher education institutions to switch to lean production standards by applying a process approach with quality assurance in accordance with ICO 9000 standards. Decree «On National Goals and Strategic Development Tasks of the Russian Federation for the Period until 2024», State Program of the Russian 
Federation «Development of education», National project «Increasing labor productivity», Project of the Russian Federation «Modern digital educational environment" identified the following main directions: ensuring the participation of the Russian Federation in the international comparative studies of the quality of general and vocational education; improvement and implementation of the procedures and methodologies for assessing the students' mastering level of the main study programs of general and vocational education, etc. [4].

Thus, there is a need to increase the level of consistency in our country's approach to the implementation of the Sustainable Development Goals, in particular the more complete inclusion of social aspects of sustainable development in national strategic planning documents, especially in terms of improving the quality of education through the introduction of the University's lean model.

KFU were granted the right to receive a subsidy from the Ministry of Education and Science in order to work towards increasing their competitiveness among the world leading scientific and educational institutions (Russian State Project 5-100-2020).

$\mathrm{KFU}$ is aimed at the active entry into the world educational and scientific space and considers international cooperation as one of the priority activities. The KFU internationalization strategy, developed in 2013, is focused on solving the following tasks:

- Development of strategic partnerships and networking with leading universities, research centers and organizations in Europe.

- Expansion of the export of educational services to European countries.

- Attracting foreign experts with the working experience in the leading universities and research centers.

- Building an effective management system of the internationalization process.

OSU named after I.S. Turgenev is flagship regional university. In the strategic program for the development of a flagship university and a roadmap, special attention is paid to improving the quality of education and the decomposition of the governance structure in accordance with the requirements of the new economy and the principles of sustainable development. The project objectives also match to the Strategy of Social and Economic Development of the Oryol Region 2020, dated December 2, 2013, No. 435-p.

The development program of OSU named by I.S. Turgenev as a flagship regional university in the modernization block of educational activity and in the modernization block of the management process includes the use of modern management technologies to improve the quality of education

In OSU there is a need to solve a number of tasks:

- improving the quality of the University's activities based on European approaches;

- formation of a unified decision support system based on the Lean University model;

- improving the competence of managers, teachers and employees in the field of quality assurance in the conditions of line management;

- involvement of stakeholders in the quality assurance process;

- implementation of best practices for the implementation of innovative technologies in the educational process;

- implementation of line management in the management system to ensure sustainability of development.

While traditional approaches to process management in the universities and, consequently, the traditional level of quality of education can hinder higher education institutions to develop in accordance with the trends of the new economy, which from one side makes demands new approaches to the processes of formation and transfer of knowledge management in universities to enhance quality in higher education, and on the other hand provides an unprecedented opportunity to improve the quality management in higher education, ensuring transparency and reliability of the results of external evaluation of 
universities through the use of modern tools and approaches.

The European Union pays significant attention to improving the quality and relevance of education through rethinking education and using the transformational advantage of new information technologies, including to increase the competence and motivation of teachers and researchers.

In the European area, there are positive trends towards higher transparency requirements in higher education systems and the need to develop quality assurance strategies in higher education [5-8]. The quality of education is considered as one of the 17 goals of sustainable development, which also increases the importance of studying the best European practices and spreading them on the territory of Russia. (Europe 2020 Strategy, Sustainable development in the European Union - Monitoring report on progress towards the Sustainable Development Goals in an EU context — the 2019 edition, The Digital Economy and Society Index DESI 2019) [9].

External quality assurance is also an important issue. Despite the fact that external evaluation is conducted by the state in the universities of the consortium of partner countries, the participation of stakeholders is increasingly taken into account for quality assurance purposes, but at the level of business structures and not enough at the level of students and the public.

Global economic developments, developing digital economic and growing international interdependence bring forward the need for international collaboration in different domains. This also applies to the educational domain and the implement of modern management technologies in HEI [10-13]. The growth of emerging Asian economies and the increasing interdependence between Europe and Asia drive the need for quality assurance skills in HEI's systems to bridge cultural differences and traditions. Russian universities have a unique opportunity to combine the culture and experience of both European and Asian civilizations, while having their own background based on a unique and complex historical path.

One of the objectives is to develop a system of criteria and indicators of the university management quality based on lean principles. Undoubtedly, in the era of the development of the global knowledge economy, university education will not remain the same. New tools and technologies are being introduced in all areas of the university, namely, in the content of education, in the applied educational technologies, in the control of knowledge, in the organization of the educational process, in the monitoring system, etc.

Also, countries and institutions will improve the involvement of not only the state, but also other stakeholders in the process of quality assurance and assessment based on modern lean technologies integrated on the basis of the lean university model [14].

A feature of the activities of universities is that the implementation of internal processes is directly related to interaction with stakeholders. The main process is educational, aimed at interacting with students, science is associated with scientific communities and individual scientists, even current management, in the conditions of the implementation of mainly the model of state universities of Russia, is based on regular communications and monitoring with the Ministries. As a result of that, the need for a digital tool to ensure the implementation of communication channels, exchange of best practices, the formation of a kind of aggregator in a transparent and reliable information environment that provides, on the one hand, an increase in the quality level of universities, on the other, a demonstration of the results of quality improvement, and on the third, a database of best practices and cases and the implementation of the Lean University model based on the process approach arises.

Thus, based on the online platform, built on the modular principles, universities will interact with the stakeholders under the implementation of the Lean-University model main processes and an information service environment will be formed to implement the LeanUniversity model for quality improvement purposes.

Subsequently the E-Lean-Hub will be expanded according to the network principle. This 
will ensure, on the one hand, the dissemination of lean management principles at universities and the best European quality assurance practices, and on the other hand, it will increase the effectiveness of university management..

The existing legislative framework of Russia does not contradict the introduction of lean management in universities, and the national projects on Education, Science, Increasing labor productivity, and the Digital Economy actually encourage the introduction of lean tools in the practice of university management.

Finally, by improving the skills of target groups (managers, employees, teachers), this project for creating a digital e-Lean-Hub service in the lean University model (hereinafter referred to as the project) will contribute to a synergistic effect in terms of quality assurance and the spread of a quality ideology with an increase in the level of social activity.

A single open and transparent educational system based on the Lean University-model will ensure the mobility of students and teachers, attract foreign teachers, organize foreign internships, student exchanges, international research, etc.

In this regard, the compliance of the quality level with international standards and the improvement of the management system is a priority in the University Development Strategy [15-16].

The project of lean universities is some integrated systems with a set of interconnected processes based on a lean office and the use of modern communication technologies and information services.

Creation of an educational system of the University based on the lean management model, expanding the use of service-oriented architectures in this management are closely related to the improvement of university education.

The development of lean model in a single university is not yet an indicator of quality of education. In order to learn how to use it in a most effective way, experience of the foreign universities where such a model is already well applied and developed is crucial. In this regard, when introducing this model, it is necessary to take into account the best practices of European universities that already have successful experience in using this system.

A single open and transparent educational system, based on the lean management model, will ensure the mobility of students and teachers from the regions of partner countries, as well as from other EU countries. It will also allow attracting foreign teachers, organizing foreign internships, student exchanges, international studies, etc. Such events will allow universities to become part of the international educational system, and preserve their unique qualities and competitive advantages [17].

\section{Conclusion}

In the knowledge economy, education and science are the main sector of the increment in value added in the society.

The study and implementation of the Lean model will allow the European education system to add value through increasing the systemic application of modern management technologies, cooperation in an international consortium and improving the quality of educational activities, and improving the culture of quality assurance.

The results of the implementation of lean-model university and the experience gained during its implementation will give significant momentum for further development based on the Lean University model not only partner universities, but also all education systems in partner countries.

The transition to a lean-university in the Russia involves to introduce more flexible and seamless processes, to change the corporate culture, streamlining processes, increase transparency and operational efficiency, and to adhere quality assurance. 


\section{References}

1. K. Bizhanova, A. Mamyrbekov, I. Umarov, A. Orazymbetova, A. Khairullaeva, E3S Web of Conferences, 135, 04023 (2019)

2. I. M. Umarov, Journal of Advanced Research in Law and Economics, 3(13), 104-111 (2015)

3. N. A. Tovma, N. B. Shurenov, L. A. Bimendiyevaa, Z. T. Kozhamkulova, and Z.B. Akhmetova, Uncertain Supply Chain Management, 8, 1-16 (2020)

4. Official Internet portal legal information: State system of legal information http://publication.pravo.gov.ru

5. B. Yedilbayev, Z. Kozhamkulova, S. Abdikul, N. Tulebayeva, E3S Web of Conferences, 135, 02011 (2019)

6. S. A. Kucheryavenko, I. V. Chistnikova, B. A. Thorikov; A. N. Nazarova, Turismoestudos e praticas, 2 (2019)

7. S. A. Kucheryavenko, I. V. Chistnikova, S. A. Gayvoronskaya, A. S. Glotova, Turismoestudos e praticas, 2 (2019)

8. I. Maslova, A. Frolov, A. Uzharinskyi, Society, integration, education, V, 357-368 (2018)

9. Communication from the commission Europe $2020 \mathrm{https}$ ://ec.europa.eu/

10. N. Gricuk, Jekonomika i predprinimatel'stvo, 4(2), 868-871 (2015)

11. A. Karpov, Voprosy jekonomiki, 3, 58-76 (2017)

12. L. Erohina, L. Savenkov, Azimut nauchnyh issledovanij: jekonomika i upravlenie, 1, 41-43 (2014)

13. S. Avruckaja, A. Kopylova, Uspehi v himii i himicheskoj tehnologii, 4, 104-106 (2014)

14. M. Vjejder, Al'pina Biznes Buks, 124 (2011)

15. A. Karpov, Obshhestvennye nauki i sovremennost', 5. 86-101 (2015)

16. R. Aetdinova, A. Nikolaeya, O. Demyanova, Lean Management and Smart Education, 14, 74-86 (2019)

17. Ziyadin, S., Serikbek, A. Internet-Marketing in the Sphere of Higher Education //Lecture Notes in Networks and Systems 84, P. 290-297 (2020) 